\title{
GRANULAR CELLS IN A BENIGN PAROTID GLAND TUMOUR: AN ATTEMPT TO UNDERSTAND ITS PROBABLE HISTOGENESIS
}

T. George, R.B. Zain, M.T. Abraham. Granular cells in a benign parotid gland tumour: An attempt to understand its probable histogenesis. Annal Dent Univ Malaya 2011; 18: 30-35.

\begin{abstract}
Tumours that occur in the oral cavity may contain granular cells as a component of their pathology. A more common granular cell lesion occurring in the head and neck region is the granular cell tumour (GCT) that usually arises in the tongue or the buccal mucosa. Granular cell tumours are very rare in the parotid gland with only 11 cases previously reported in the English literature. We report a case of a benign tumour involving the parotid gland of a young female patient. The case was diagnostically challenging due to the large proportion of granular cells masking the underlying pathology. Histopathological features and immunohistochemical analysis favoured a diagnosis of a benign GCT. The present report provides an insight into the differential diagnosis and attempts to characterise the granular cells with the use of the wellestablished immunohistochemical markers and conventional histopathological techniques.
\end{abstract}

Key words: granular cell tumour, histogenesis, S-100, NSE, schwannoma, CD-68.

\section{INTRODUCTION}

Granular cells are characteristic pathological components of many tumours and lesions that occur in the oral cavity. Granular cell odontogenic fibromas, granular cell ameloblastomas, congenital epulis of the newborn (CEN) and oral lichen planus may contain these cells to different extents $(1,2)$. The granular cell tumour, originally described by Abrikossof in 1926 is an uncommon benign tumour that may frequently arise in the tongue, skin and subcutaneous tissues $(3,4,5)$. Although very uncommon, a malignant counterpart of GCT has also been described. GCT occurs very rarely in the parotid gland with only 11 cases reported previously in the English-language literature (6). This report describes in detail the clinicopathologic and immunologic profile of a benign parotid gland tumour demonstrating a prominent granular cell change.

Case Report

T. George ${ }^{1}$, R.B. Zain ${ }^{1,2}$, M.T. Abraham ${ }^{3}$

${ }^{1}$ Department of Oral Pathology,

Oral Medicine and Periodontology,

${ }^{2}$ Oral Cancer Research and Coordinating Center,

Faculty of Dentistry, University of Malaya,

50603, Kuala Lumpur, Malaysia.

Tel No (Office): +603-79674808

Fax: $+603-79674831$

Email: thomasg22@um.edu.my

${ }^{3}$ Department of Oral \& Maxillofacial Surgery,

Hospital Tengku Ampuan Rahimah,

Jalan Langat, 41200, Klang, Selangor, Malaysia.

Corresponding author: Dr. Thomas George Kallarakkal

\section{CASE REPORT}

\section{Clinical findings:}

A 26 year old Indian woman was referred to the Department of Oral and Maxillofacial Surgery, Tengku Ampuan Rahimah Hospital (HTAR), Klang for expert management of a swelling over the right posterior auricular region (Fig. 1). FNAC was done in 2006 and it revealed a basal cell adenoma of the right parotid gland. Upon examination, the swelling was mildly tender to palpation, lobulated and firm in consistency with a maximum dimension of $4 \mathrm{~cm}$. CT scan revealed a uniformly dense, well defined, lobulated right parotid gland with cystic spaces in the medial aspects of the superior and the deep lobe of the parotid gland (Fig. 2). Persistence of fat spaces was observed. Cervical lymphadenopathy was present and there was no evidence of vascular invasion or bony erosion. A superficial parotidectomy was performed under general anesthesia and the specimen was submitted for histopathological examination. At a 16 - month follow - up there was no evidence of any recurrence.

\section{Macroscopic findings:}

The gross specimen consisted of a part of parotid salivary gland with a lobulated surface measuring $4.5 \times 3.5 \times 3.0 \mathrm{~cm}$. The cut sections showed multiple cystic areas containing yellowish jelly like material. The remaining areas appeared firm and yellowish brown in colour. 


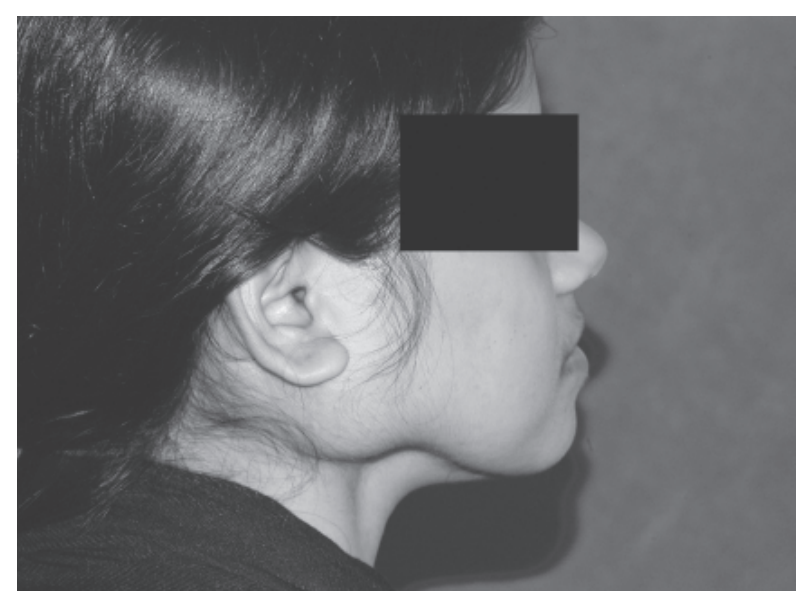

Figure 1. Swelling over the right posterior auricular region.

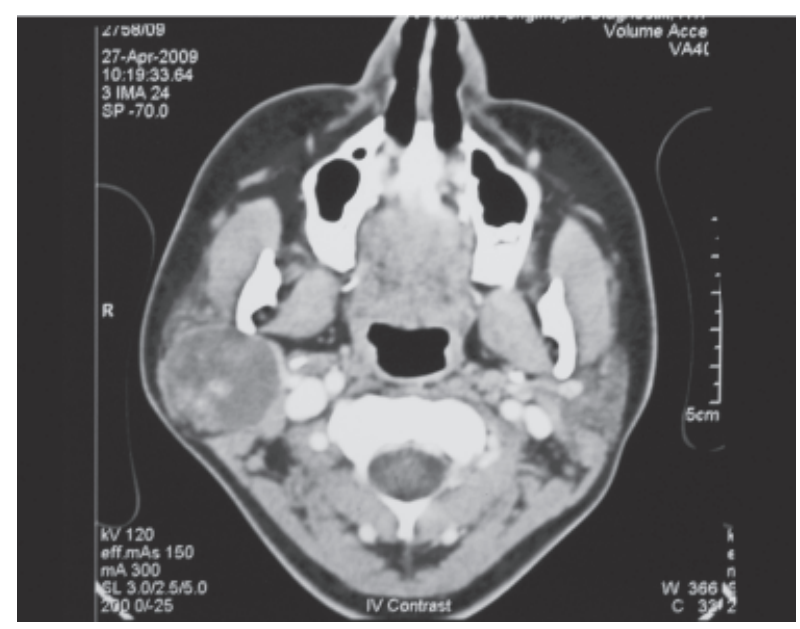

Figure 2. CT scan showing a well defined lesion in the region of the right parotid gland.

\section{Microscopic features:}

The tumour was well encapsulated and composed of sheets of granular cells intermingled with spindle cells (Fig. 3). The granular cells were round to polyhedral with an eosinophilic, coarsely granular cytoplasm and indistinct cell borders. The nuclei ranged from small, dark and hyper chromatic to large with a vesicular chromatin pattern. The nuclei were located either in a peripheral or central location. The spindle cells in the tumour showed an eosinophilic cytoplasm, and a centrally located vesicular nucleus. These cells were arranged in interwoven fascicles at least focally (Fig. 4). The tumor showed focal areas of cystic degeneration and the granular cells appeared to be related to these degenerating areas. In addition, loosely textured areas akin to myxomatous areas were also observed. Salivary glandular ductal elements were present in an extracapsular location. The granular cells showed faint intra-cytoplasmic Periodic Acid Schiff (PAS) staining after digestion with diastase. Negative staining was observed with Mucicarmine and Alcian blue stains.
Immunohistochemical staining demonstrated a strong positive reaction of the lesional cells to CD68 (Fig. 5) and Vimentin (Fig. 6). The spindle cells demonstrated strong nuclear and cytoplasmic staining to S-100 protein while the granular cells demonstrated only weak cytoplasmic staining (Fig. 7). Reactivity of the lesional cells to neuron specific enolase (NSE), pancytokeratins, glial fibrillary acidic protein (GFAP), desmin and smooth muscle actin was negative. The source and dilutions used for antibodies are documented in Table 1. Based on the clinical, histopathological and immunohistochemical features the lesion was diagnosed as a benign granular cell tumour of the parotid gland.

\section{DISCUSSION}

Granular cell tumour was originally termed granular cell myoblastoma because the granular cells often appeared to arise from or lie close to skeletal muscle bundles $(1,4)$. Ultra structural studies have suggested altered Schwann cells or undifferentiated mesenchymal cells as the cellular origin of this tumor (4). The membrane bound vacuoles resembling secondary lysosomes that give the cell in GCTs their characteristic granular appearance have been found to resemble myelin ultra-structurally thereby supporting a Schwann cell origin (5). The histogenesis of GCTs has been the subject of extensive immunohistochemical analysis. S-100 protein is one of the most widely used markers for identification of the granular cells. Traditionally, S-100 antibodies have been proved to be useful in the identification of tumours that arise from the neural crest (7). Besides GCTs, positive S-100 staining is observed in melanomas, poorly differentiated carcinomas, peripheral nerve sheath tumors and tumors that contain myoepithelial cells (8). Granular cell lesions that do not stain with S-100 have been reported by LeBoit et al (9). They termed these lesions primitive polypoid granular cell tumour and non-neural granular cell tumour (NNGCT) respectively. Lerman and Freedman reported the first intra oral example of an NNGCT. The reported findings in their case were consistent with previous reports in that there was a strong diffuse positivity for NK1-C3 (CD63), Vimentin and negative reactivity for S-100 and $\operatorname{NSE}(9,10)$.

The monoclonal antibody NK1-C3 (CD63) was initially raised against the gp100 group of glycoproteins present in the cells of melanocytic origin. However it has been observed that positivity to CD63 does not reflect a specific line of cellular differentiation as it has also been demonstrated in degenerating cells and non-melanocytic tumors. Nevertheless this antibody is still regarded as a very sensitive immuno-histochemical marker of granular cell change irrespective of the histogenesis (8). 


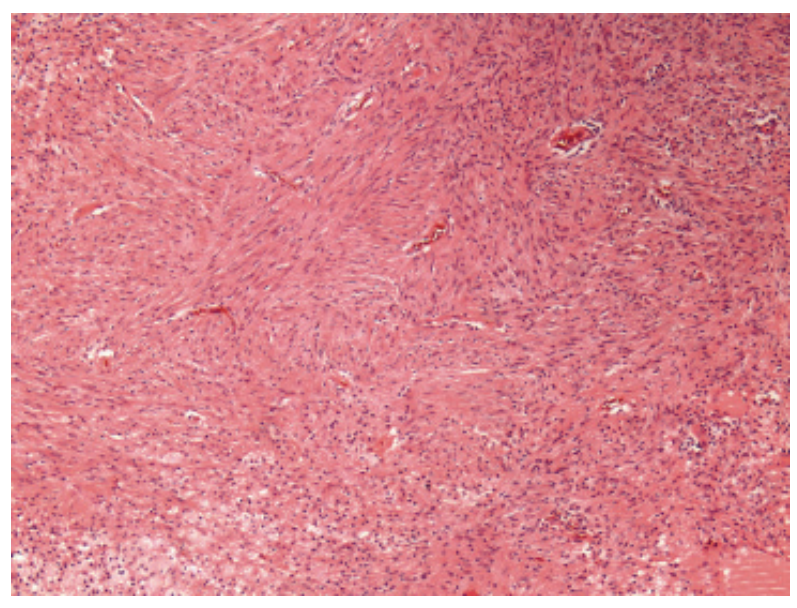

Figure 3. Well encapsulated tumor showing sheets of granular cells intermingled with spindle cells (Original Magnification 40x).

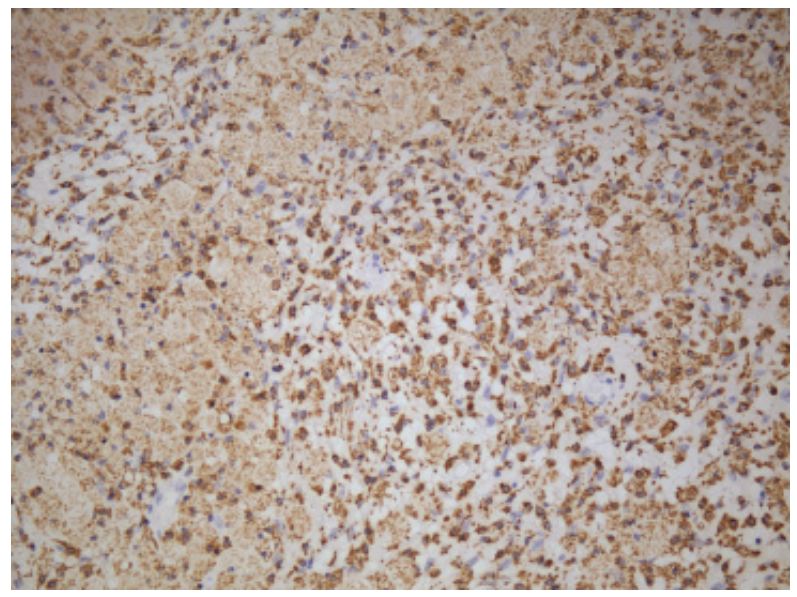

Figure 4. Spindle cells arranged in interwoven fascicles (Original Magnification 100x).

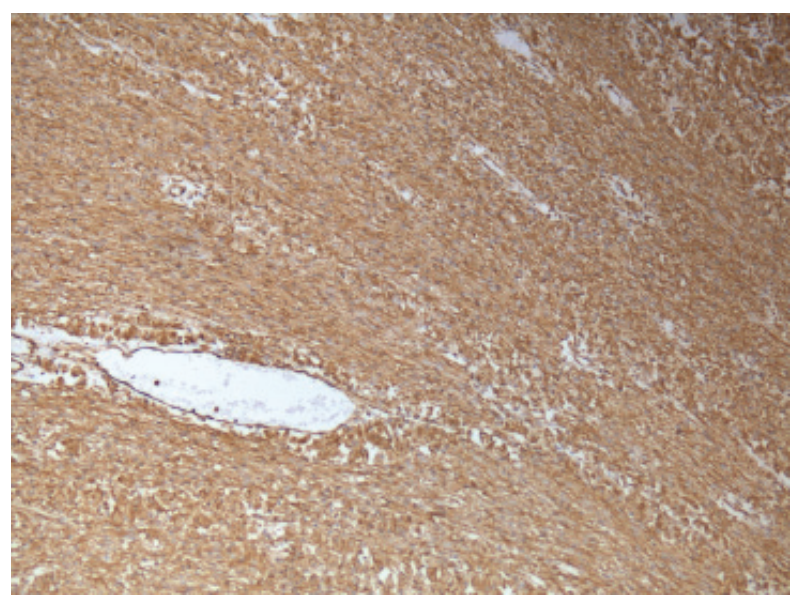

Figure 5. Granular cells stained positive for CD68 (Immunoperoxidase Envision technique, Original Magnification 200x).

Neuron specific enolase (NSE) is a marker for neural and neuro-endocrine cells. Positive staining with NSE is observed in GCTs but Schwann cells stain negative. This suggested the probability of GCTs being neuroendocrine in origin (5). Glial fibrillary

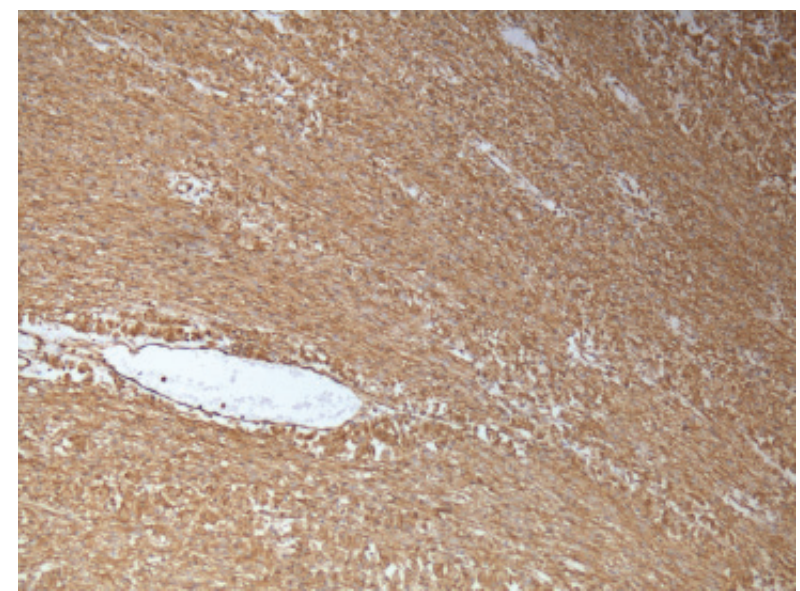

Figure 6. Lesional cells stained positive for Vimentin (Immunoperoxidase Envision technique, Original Magnification 100x).

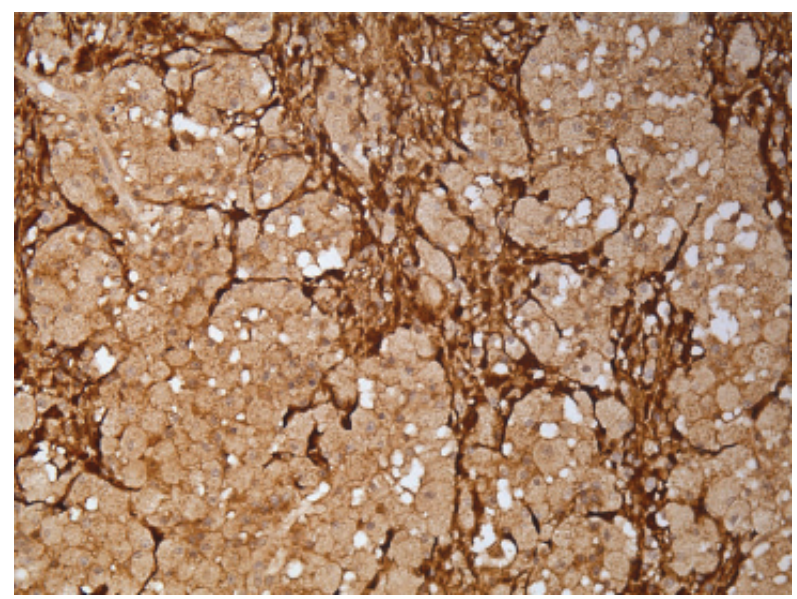

Figure 7. Weak cytoplasmic staining of the granular cells to S-100 protein (Immunoperoxidase Envision technique, Original Magnification 100x).

acidic protein (GFAP) may be seen in a variety of nonglial tumors ranging from pleomorphic adenomas of the salivary glands to pheochromocytomas. Schwann cells and Schwannomas stain for glial fibrillary acidic protein (GFAP), but GCTs are negative. These differences suggested that GCTs may not arise from Schwann cells (5). Vimentin is ubiquitously expressed by mesenchymal tissues. It is not cell - type specific. Both GCTs and Schwannomas stain positively for vimentin $(5,8)$.

Salivary gland neoplasms including mixed tumours, oncocytomas, mucoepidermoid carcinomas, acinic cell adenocarcinomas, polymorphous low grade adenocarcinomas and adenoid cystic carcinomas may commonly contain varying proportions of clear cells. Diagnosis can be challenging when these clear cells constitute the major cellular component. However classification of these tumours would be based on the morphological and histological growth patterns typical of the tumours (11). The present case did not show any histomorphological evidence of an epithelial neoplasm. Mesenchymal tumours of salivary glands 
Table 1

\begin{tabular}{|c|c|c|c|c|c|c|c|c|}
\hline No. & $\begin{array}{l}\text { Primary } \\
\text { antibody }\end{array}$ & Type & Company & Code & Dilution & Ag retrieval buffer & Wash Buffer & Treatment \\
\hline 1. & SMA & $\begin{array}{l}\text { Monoclonal mouse } \\
\text { Anti-Human }\end{array}$ & Dako & M085101 & $1: 500$ & Tris-EDTA pH 9.0 & TBS pH 7.6 & $\begin{array}{l}\text { Microwave } \\
\left(99^{\circ} \mathrm{C}\right)-10 \text { mins }\end{array}$ \\
\hline 2. & Vimentin & $\begin{array}{l}\text { Monoclonal mouse } \\
\text { Anti-Vimentin }\end{array}$ & Dako & M072501 & $1: 2000$ & Tris-EDTA pH 9.0 & TBS pH 7.6 & $\begin{array}{l}\text { Microwave } \\
\left(99^{\circ} \mathrm{C}\right)-20 \text { mins }\end{array}$ \\
\hline 3. & Desmin & $\begin{array}{l}\text { Monoclonal mouse } \\
\text { antibody }\end{array}$ & Dako & M076001 & $1: 200$ & Tris-EDTA pH 9.0 & TBS pH 7.6 & $\begin{array}{l}\text { Microwave } \\
\left(99^{\circ} \mathrm{C}\right)-20 \text { mins }\end{array}$ \\
\hline 4. & NSE & $\begin{array}{l}\text { Monoclonal mouse } \\
\text { Anti-Human NSE }\end{array}$ & Dako & M0873 & $1: 1000$ & Tris-EDTA pH 9.0 & TBS pH 7.6 & $\begin{array}{l}\text { Microwave } \\
\left(99^{\circ} \mathrm{C}\right)-12 \text { mins }\end{array}$ \\
\hline 5. & CD68 & $\begin{array}{l}\text { Monoclonal mouse } \\
\text { Anti-Human CD68 }\end{array}$ & Dako & M0876 & $1: 300$ & Tris-EDTA pH 9.0 & TBS pH 7.6 & $\begin{array}{l}\text { Microwave } \\
\left(99^{\circ} \mathrm{C}\right)-20 \text { mins }\end{array}$ \\
\hline 6. & $\mathrm{~S} 100$ & $\begin{array}{l}\text { Rabbit Anti-Cow, } \\
\text { polyclonal antibody }\end{array}$ & Dako & Z031101 & $1: 3000$ & Tris-EDTA pH 9.0 & TBS pH 7.6 & $\begin{array}{l}\text { Microwave } \\
\left(99^{\circ} \mathrm{C}\right)-15 \text { mins }\end{array}$ \\
\hline 7. & GFAP & $\begin{array}{l}\text { Monoclonal mouse } \\
\text { Anti-Human GFAP }\end{array}$ & Dako & M0761 & $1: 3000$ & Tris-EDTA pH 9.0 & TBS pH 7.6 & $\begin{array}{l}\text { Microwave } \\
\left(99^{\circ} \mathrm{C}\right)-15 \text { mins }\end{array}$ \\
\hline 8. & $\begin{array}{l}\text { CK } \\
\text { (Clone } \\
\text { MNF116) }\end{array}$ & $\begin{array}{l}\text { Monoclonal mouse } \\
\text { antibody }\end{array}$ & Dako & M0821 & $\begin{array}{l}\text { TBS } \\
\mathrm{pH} 7.8\end{array}$ & $\begin{array}{l}\text { Trypsin } \\
\text { (Proteolytic } \\
\text { technique) }\end{array}$ & TBS pH 7.6 & $\begin{array}{l}\text { Microwave } \\
\left(37^{\circ} \mathrm{C}\right)-2 \text { mins }\end{array}$ \\
\hline
\end{tabular}

Source, dilution of antibodies and laboratory procedures for immunostaining employed in the study

are very rare with a reported incidence ranging from $1.9-5 \%$. Haemangiomas, lipomas and neurogenic tumours are the most common forms of benign tumours involving the salivary glands (12). Immunohistochemical analysis contributed to our diagnosis as a positive staining with S-100 protein confirmed the neurogenic nature of the lesion in the present case. Presence of a well-defined capsule and lack of infiltrative characteristics eliminated the possibility of a salivary gland malignancy.

The imunohistochemical findings in our case were not characteristic. The spindle cells and the granular cells stained positively for S-100 protein and Vimentin. Although it is popularly believed that S-100 antigen is expressed by all neoplastic Schwann cells, it is known to have a wider distribution and hence may not probably be a reliable marker to establish the neurogenic origin of any lesion (5). The site of the lesion in our case being the parotid gland and the arrangement of the spindle cells in interlacing fascicles admixed with areas of myxoid degeneration prompted us to include a myoepithelioma in our differential diagnosis. However, the negative immunoreactivity for cytokeratins, glial-fibrillary acidic protein GFAP) and smooth muscle actin ruled out a myoepithelial origin for the lesional cells.

Fibrous histiocytomas in the major salivary glands are rare. They are unencapsulated lesions composed of an admixture of fibroblasts and histiocyte like cells (13). The presence of short intersecting fascicles of fibroblast like spindle cells and granular cells resembling foamy histiocytes in our case led to the inclusion of a benign fibrous histiocytoma in our differential diagnosis. However a positive immunoreactivity of the lesional cells for S-100 protein coupled with the presence of a well-defined capsule and absence of any form of giant cells in the present case eliminated this probable diagnosis.

A positive diffuse staining was observed with $\mathrm{CD}$ 68. Positive immunoreactions to these antibodies may be found in cells of macrophage lineage and occasionally in cells of fibroblastic or Schwannian lineages. CD-68 is organelle specific rather than lineage specific. GCTs usually stain positive for CD68 and it is explained by the assumption that Schwann cells acquire lysosomes during phagocytosis of myelin (8). The strong positivity of the granular and the spindle cells to CD-68 in the present case may be attributed to their lysosomal content. The accumulation of large numbers of lysosomes within the cells may represent an enzymatic defect in the lysosomes or the synthesis of excessive amounts of myelin material by the tumour cells (14). Since both the spindle cells and the granular cells were intimately related to each other and demonstrated almost similar immunoreactivity with all the employed markers they may be considered to represent an identical lineage. The granular cells may actually be the manifestation of a metabolic change that was initiated in the spindle shaped Schwann cells.

Granular cell changes have been reported in smooth muscle tumours of skin and soft tissue (14). Negative immunoreactivity with smooth muscle actin and desmin negated a probable myogenous histogenesis for the lesional cells.

Granular cell reaction is a phenomenon characterized by the accumulation of histiocytes with granular cytoplasm at sites of surgical trauma. These histiocytic reactions bear a close resemblance to GCTs (15). In 1964 Sobel and Churg defined simple histologic and histochemical criteria for differentiating granular cell myoblastoma from a granular cell reaction 


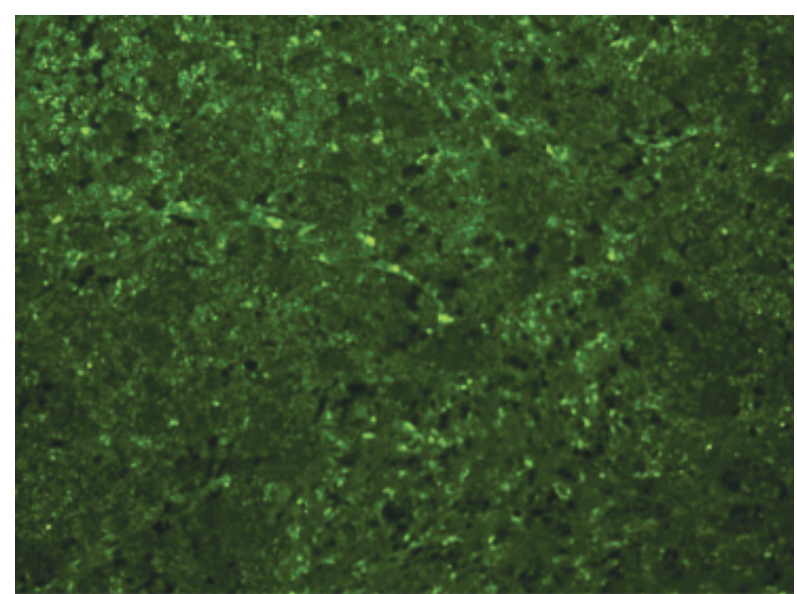

Figure 8. Unstained formalin fixed paraffin embedded tissue section under the fluorescence microscope reveals a faint green fluorescence (Original Magnification 100x).

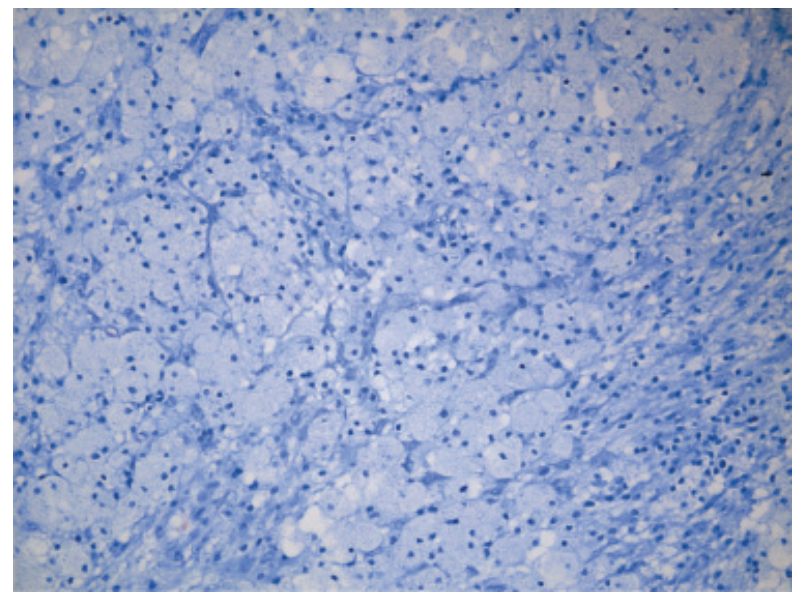

Figure 9. The granular cells were not acid-fast (Ziehl-Neelsen stain, Original Magnification 20x).

(16). Sobel et al described the reactive granular cells to be acid fast and autofluroscent giving an orangebrown fluorescence. However in our case the granules did not demonstrate these features (Figs. 8 \& 9). A feature that is frequently found in granular cell reaction is accumulation of nodules of granuloamorphous debris similar to the cytoplasmic granular material (15). The cystic areas associated with the degenerating granular cells within the lesion seen in our case may actually represent the nodules of granulo-amorphous debris described by Sobel et al. However there was no histological evidence of any other significant inflammatory component within the lesion. Ct scans also revealed the persistence of fat spaces within the lesion, a feature that is hardly observed in inflammatory lesions. The only possible inciting factor for a granular cell reaction would have been the fine needle aspiration biopsy performed for the same lesion three years ago.

The present case may be best regarded as a Schwannoma exhibiting granular cell change. Microscopic findings favoring a Schwannoma were encapsulation and arrangement of the spindle cells in whorls and interlacing fascicles (Antoni A areas) alternating with the less orderly and less cellular (Antoni B) areas. Moreover, the lesional cells reacted positively with S-100 protein and Vimentin. The granular cells may represent the degenerative change occurring in a pre-existing Schwannoma but such degenerative cells would not have stained positively for S-100 protein (1). Vimentin staining was diffuse and cytoplasmic in nature. This was in contrast to the distinctive peripheral cytoplasmic reaction pattern in cells of the granular cell tumour. A negative staining with neuron specific enolase (NSE) ruled out a deviant differentiation pattern of the granular cells. The diffuse granular staining pattern with CD-68 highlighted the presence of lysosomes within the lesional cells. Hence we conclude that the present case is a granular cell schwannoma or a benign granular cell tumour (17).

Further immunostaining with calretinin, alphasubunit of inhibin, PGP9.5, p75/NGFR, Leu-7, MBP, NK1/ C-3, $\alpha_{1}-$ antichymotrypsin (AACT) and cathepsin $\mathrm{B}$ could be performed to validate the diagnosis of $\operatorname{GCT}(3,18,8)$. Calretinin is primarily expressed in certain subtypes of neurons in the central and peripheral nervous systems. Inhibin, a polypeptide hormone consisting of two subunits is secreted primarily by ovarian granulosa cells and sertoli cells. Fine et al demonstrated the usefulness of these two markers in the diagnosis of GCTs (3). Mazur et al reported reactivity of GCTs to AACT and cathepsin B which are histiocytic markers. The presence of these two markers in GCTs has been related to the formation of many phagolysosomes in these tumours (18). The protein gene product 9.5 (PGP9.5) has a wide spectrum of distribution including neuronal and neuroendocrine cells and has been found to be expressed in GCTs. p75 immunoreactivity has been reported in a large group of fetal and adult tissues as well as in neural, non-neural and oral granular cell tumours (8). Myelin basic protein (MBP) and Leu-7, markers for myelin glycoprotein have been demonstrated in GCTs (18).

The present case is reported to highlight the variable histomorphologic and staining patterns of the lesional cells. The location of the tumor coupled with the uncertainty regarding the histogenesis of the granular cells added to the difficulty in establishing a final diagnosis. Cytoplasmic granularity has been observed in cells from a variety of conditions that include benign and malignant tumours and reactive lesions. We confer with the views of Vered et al that the appearance of granular cells is not limited to one cell type and the cell of origin may differ according to its accessibility at any site (8).

In regards to the present case the granular change may be considered as an expression of a metabolic change in the Schwann cells since a reactive pathogenesis could not be established and hence may not warrant consideration as a distinct histopathological entity. 


\section{REFERENCES}

1. Basile JR, Woo S-B. Polypoid S-100-negative granular cell tumor of the oral cavity: A case report and review of literature. Oral Surg Oral Med Oral Pathol Oral Radiol Endod 2003; 96: 70-6.

2. van der meij EH, van der waal I. Granular cells in oral lichen planus. Oral Diseases 2001; 7: 116-118.

3. Fine SW, Li M. Expression of calretinin and the alpha subunit of inhibin in granular cell tumors. Am J Clin Pathol 2003; 119: 259-64.

4. Miettinen M, Lehtonen E, Lehtola H, Ekblom P, Lehto VP, Virtanen I. Histogenesis of granular cell tumor - An immunohistochemical and ultrastructural study. J Pathol 1984; 142: 221-9.

5. Williams HK, Williams DM. Oral granular cell tumours: a histological and immunocytochemical study. J Oral Pathol Med 1997; 26: 164-9.

6. Bomfin LE, Alves F de Abreu, Almeida OP, Kowalski LP, Perez DE da Cruz. Multiple granular cells of the tongue and parotid gland. Oral Surg Oral Med Oral Pathol Oral Radiol Endod 2009; 107: e10-e13.

7. O'Leary TJ, Frisman DM. Antigens. In: O' Leary TJ editor. Advanced diagnostic methods in Pathology. Pennsylvania: Saunders; 2003. pp.6364.

8. Vered M, Carpenter WM, Buchner A. Granular cell tumor of the oral cavity: updated immunohistochemical profile. J Oral Pathol Med 2009; 38 : 150-9.

9. LeBoit PE, Barr PJ, Burall S, Metcalf JS, Benedict TS, Wick MR. Primitive polypoid granular-cell tumor and other cutaneous granular-cell neoplasms of apparent nonneural origin. Am J Surg Pathol 1991; 15: 48-58.
10. Lerman M, Freedman PD. Nonneural granular cell tumor of the oral cavity: a case report and review of the literature. Oral Surg Oral Med Oral Pathol Oral Radiol Endod 2007; 103: 382-4.

11. Ellis GL. Clear cell neoplasms in salivary glands: clearly a diagnostic challenge. Ann Diag Pathol 1998; 2: 61-78.

12. Cho KJ, Ro JY, Choi J, Choi SH, Nam SY, Kim SY. Mesenchymal neoplasms of the major salivary glands: clinicopathological features of 18 cases. Eur Arch Otorhinolaryngol 2008; 265(Suppl 1): S47 - S56.

13. McDaniel RK. Benign mesenchymal neoplasms. In: Ellis GL, Auclair PL, Gnepp DR editors. Surgical pathology of the salivary glands. Philadelphia: W.B. Saunders Company; 1991. p. $500-01$.

14. Mentzel T, Wadden C, Fletcher CD. Granular cell change in smooth muscle tumours of skin and soft tissue. Histopathology 1994; 24: 223-31.

15. Weiss WS, Goldblum JR. Benign fibrohistiocytic tumors. In: Weiss WS, Goldblum JR editors. Ennzinger and Weiss's soft tissue tumors. Missouri: Mosby; 2001. p. 481-486.

16. Sobel HJ, Arvin E, Marquet E, Schwarz R. Reactive granular cells in sites of trauma: A cytochemical and ultrastructural study. Am J Clin Pathol 1974; 61: 223-234.

17. Dheepa R, Janaki C, Gomathy N, Sentamilselvi G, Janaki VR. Granular cell Schwannoma. Indian Journal of Dermatology 2004; 49(4): 198-9.

18. Mazur MT, Shultz JJ, Myers JL. Granular cell tumor. Immunohistochemical analysis of 21 benign tumors and one malignant tumor. Arch pathol Lab Med 1990; 114: 692-6. 